\title{
Hymenopteran color preference using multiple colours of pan traps in Slovakia
}

\author{
Alexander Csanády, Jozef Oboňa, Lenka Zapletalová, L'ubomír Panigaj, \\ Dana Dojčaková \& Boris Záleta
}

\begin{abstract}
Hymenopteran color preference using multiple colours of pan traps in Slovakia. - Acta Mus. Siles. Sci. Natur. 70: 33-46, 2021.

Abstract: The study presents results of colour preference of insects (Insecta), mainly from the order Hymenoptera (families Apidae, Formicidae). The research was carried out in the vicinity of the Beniakovce village (near the Košice city) over the years 2010-2012. Trapping by coloured water traps was conducted at ten sites with 50 Moerick's water traps coloured with five different colours (white, yellow, blue, purple, and red). On the study area there were 12357 individuals captured, belonging to 17 higher taxa (class, order, suborder) or genus morpho group of families Apidae and Formicidae. The highest abundance was found in Diptera followed by Hymenoptera, Coleoptera and Lepidoptera. Obtained results were in accordance with literature data, which showed that yellow colour was the most preferred by insects. Our results confirmed high degree of diversity of insect's fauna in the study area.

Our study suggested that a modified Moerick's water traps may be a valuable tool in studies on insect diversity, distribution, seasonal abundance, and foraging behaviour as well.
\end{abstract}

Key words: Arthropods, Beniakovce village, coloured Moerick's water traps, middle Europe

\section{Introduction}

Colour of flowering plants is one of the more important attractants which plants use to attract pollinators (Kevan 1972). In addition, they also use fragrances, rewards (pollen/nectar), and size or shape of flowers (Niesenbaum et al. 1998). Leong \& Thorp (1999) showed that pollinators and other flower-visiting insects responded to common floral colours associated with floral rewards such as pollen or nectar. Therefore, colour traps were a potential method of surveying and monitoring diversity and abundance in many fields of research of pollinators as well other groups of insects.

Coloured pans filled with water and an additive (e.g., soap) to help break surface tension were the most common type of coloured traps. From all colours, the yellow was the most widely used colour because it attracts a diversity of insects. In several studies were used these types of traps to estimate relative abundances of bees or other pollinators in different habitats and evaluated their potential for comparing species richness and diversity (Leong \& Thorp 1999).

The capturing of insect with of the Moerick's water pan traps provide valuable data on the relative number of species at different habitats (Noyes 1989; Leong \& Thorp 1999; Cane et al. 2000; Beneš et al. 2000; Toler et al. 2005; Westphal et al. 2008; Buchholz et al. 2010). Above mentioned authors showed usefulness of coloured traps in research in conditions with a lack of natural nectar sources and unstable weather as well as the tree floor of tropical forests. Moreover, they predict that despite the benefits of their field use, especially in small populations located in areas with low nectar availability, their use may be destructive. Therefore, they recommend using this method with extreme caution.

Also, many other studies (e.g., Stephen \& Rao 2005; Toler et al. 2005; Campbell \& Hanula 2007; Roulston et al. 2007; Wilson et al. 2008; Tao et al. 2012; Munyuli 2013; Heneberg \& Bogusch 2014) confirmed the importance of using different types of traps in research on hymenopteran biodiversity. Extrapolating water trap samples to whole insect communities, 
however, should be done with great caution. If samples are compared, it is necessary to consider whether the samples were collected from flower-rich or flower-poor places. Only after obtaining enough data will be possible to compare whether the competition between flowers and traps creates only minimal or manageable bias.

It was reason why several authors (Noyes 1989; Cane et al. 2001; Roulston et al. 2007; Westphal et al. 2008) pointed out that traps may not accurately reflect pollinators fauna, because samples from these traps did not sufficiently represent the original bee fauna that visit flowering plants. Therefore, they recommend a combination of several methods. These include the method of catching in colour traps, but also using entomological nets, observations, standardized and variable transect walks, nesting reed traps or paper tubes. In addition, longterm monitoring is particularly important to obtain comprehensive species diversity. In addition, other parameters such as trap height, duration of trap placement, etc., could play important role in trap captures. Therefore, exploring their effects on trap captures could prove useful for maximizing insect pollinator sampling, in these habitats (Campbell \& Hanula 2007).

In Slovakia, Pidaná (2003) and Gabriková (2005) used colour water traps in research of insects. Later, several authors gained significant insights into the colour preference of flies (Straka et al. 2010), butterflies (Kočíková et al. 2012, 2014).

The main aim of this study was to complete previous knowledge's and to supplement them with new data of colour preference by other groups of insects (obtained by Záleta 2013), mainly hymenopteran which could be the basis for a more detailed evaluation in the future.

\section{Material and Methods}

Study area

Studied area was located near the Beniakovce village (Fig. 1) approximately 4 km northwest from Košice city, 48 46'04"N, $21^{\circ} 18^{\prime} 06^{\prime \prime} \mathrm{E} ; 290$ - $305 \mathrm{~m}$ a.s.l. Insect colour preference research was conducted on a north-east oriented gentle slope on abandoned pastures adjacent to forest grassland and partially ruderal vegetation with a variety of food sources consisting of multiple plant species (Kočíková et al. 2012, 2014; Csanády et al. 2018).

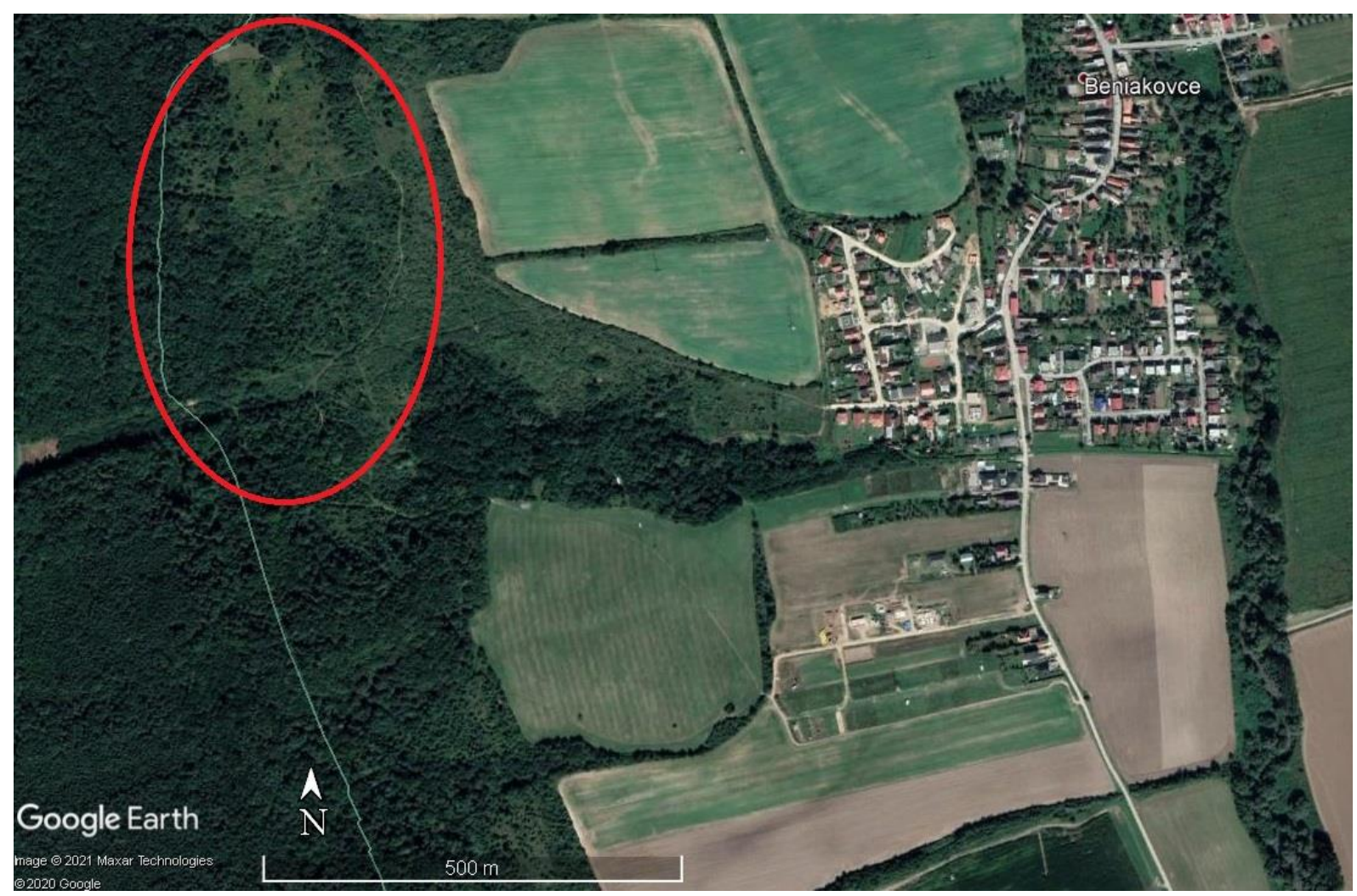

Fig 1: The study area of capturing in the vicinity of Beniakovce village (Source: C2020 Google, Image(C2021 CNES/Astrium). 


\section{Colour water traps}

In the studied locality with an area of 20 ha, 50 Moerick's colour water traps of five different colours were placed in 10 insect capture sites (Fig. 2). The water traps consisted of plastic cups (upper diameter: $12 \mathrm{~cm}$, depth $6 \mathrm{~cm}$ ) with an inner surface coloured by DUPLI-COLOR paint spray in five basic colours (white, yellow, blue, purple, and red). From the outside, each plastic cup was green. The water with detergent ( $1 \mathrm{ml} / 1$ of water) was poured into the trap to a depth of approximately $2 \mathrm{~cm}$. The traps were placed on a $30 \mathrm{~cm}$ long wire, which represented the holder and was at the same level as the surrounding vegetation (Kočíková et al. 2012; Csanády et al. 2018).

The traps were exposed for ten days in each month from April to September over a three-year period 2010 2012 (Tab. 1). At the same time, traps were distributed in all types of habitats on the studied area: xero-mesophilic grasslands, border of oak-hornbeam forests and bushes. In each of these micro-environments, 5 square-shaped traps of $2 \mathrm{~m}^{2}$ were placed. The location of the trap groups remained the same, but within the group the traps changed in colour. The trapped material was inspected and collected at two-day intervals.

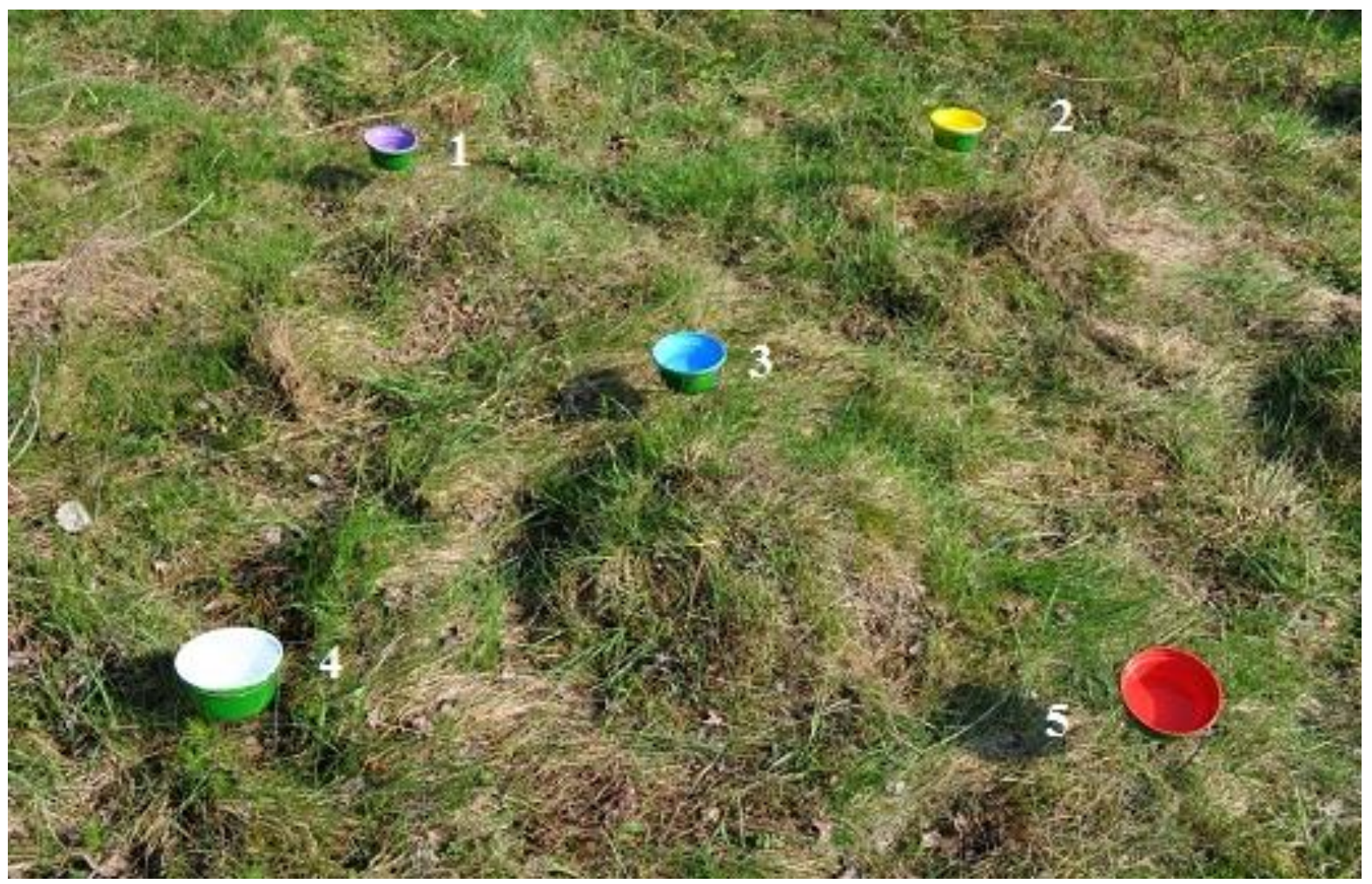

Fig 2: Sketch of Moerick's coloured water traps and the method of installation (1 - purple, $\mathbf{2}$ - yellow, 3 - blue, 4 - white, 5 - red; Photo Lenka Zapletalová).

\section{Flowers colour estimation}

The colour ratios of the blooming flowers in the studied area were obtained in each month of the growing season (from April to September) by averaging over three years (Fig. 3). For each month, the flowering species were flowers and plants blooming in the appropriate colour (determined with guide by Schauer, 2007). We confirmed the presence of blooming flowers in four colours (without red flowers) in the study area. The values obtained represent the percentage of flowers of a given colour among all flowers. It should be also noted that ratios in each month and year were estimated only approximately without a more detailed calculation per unit area. Therefore, this ratio was only our subjective view.

April: yellow flowers - 80\% (Euphorbia cyparissias L., Potentilla argentea L., Taraxacum officinale L.); white flowers - 15\% (Fragaria vesca L., Prunus spinosa L.); purple flowers - 5\% (Viola tricolor L., Veronica spicata L., Glechoma hederacea L., Trifolium pratense L.)

May: yellow flowers - 45\% (Hieracium sp., Ranunclus acris L., Euphorbia cyparissias L.); white flowers flowers - 25\% (Fragaria vesca L., Prunus spinosa L., Rosa canina L., Stellaria sp., Trifolium repens L.); purple flowers - 10\% (Medicago sativa L., Lychnis flos-cuculi L., Trifolium pratense L., Polygala vulgaris L.); blue flowers $-20 \%$ (Veronica spicata L.) 
June: yellow flowers - 85\% (Ranunclus acris L., Lotus corniculatus L., Hypericum perforatum L., Hieracium sp., Agrimonia eupatoria L.) white flowers - 5\% (Achillea millefolium L., Rubus fruticosus L.) purple flowers $10 \%$ (Dianthus deltoides L., Veronica spicata L., Medicago sativa L.).

July: yellow flowers - 59\% (Galium verum L., Lotus corniculatus L., Hypericum perforatum L., Hieracium sp., Agrimonia eupatoria L.); white flowers - 10\% (Achillea millefolium L., Daucus carota L., Stellaria nemorum L., Calystegia sepium (L.) R.Br.., Rubus fruticosus L.); purple flowers - 31\% (Epilobium angustifolium (L.) Scop., Thymus L., Cirsium arvense (L.) Scop., Medicago sativa L., Dianthus deltoides L.).

August: yellow flowers - 4\% (Lotus corniculatus L., Hypericum perforatum L., Hieracium sp., Agrimonia eupatoria L., Solidago gigantea Ait., Lathyrus pratensis L., Leontodon hispidus L.); white flowers - 95\% (Achillea millefolium L., Daucus carota L.); purple flowers - 1\% (Thymus L., Cirsium arvense (L.) Scop., Medicago sativa L., Dianthus deltoides L.)

September: yellow flowers - 20\% (Solidago gigantea Ait., Leontodon hispidus L.); white flowers - 79\% (Achillea millefolium L., Daucus carota L.); purple flowers - 1\% (Cirsium arvense (L.) Scop., Dianthus deltoides L.).

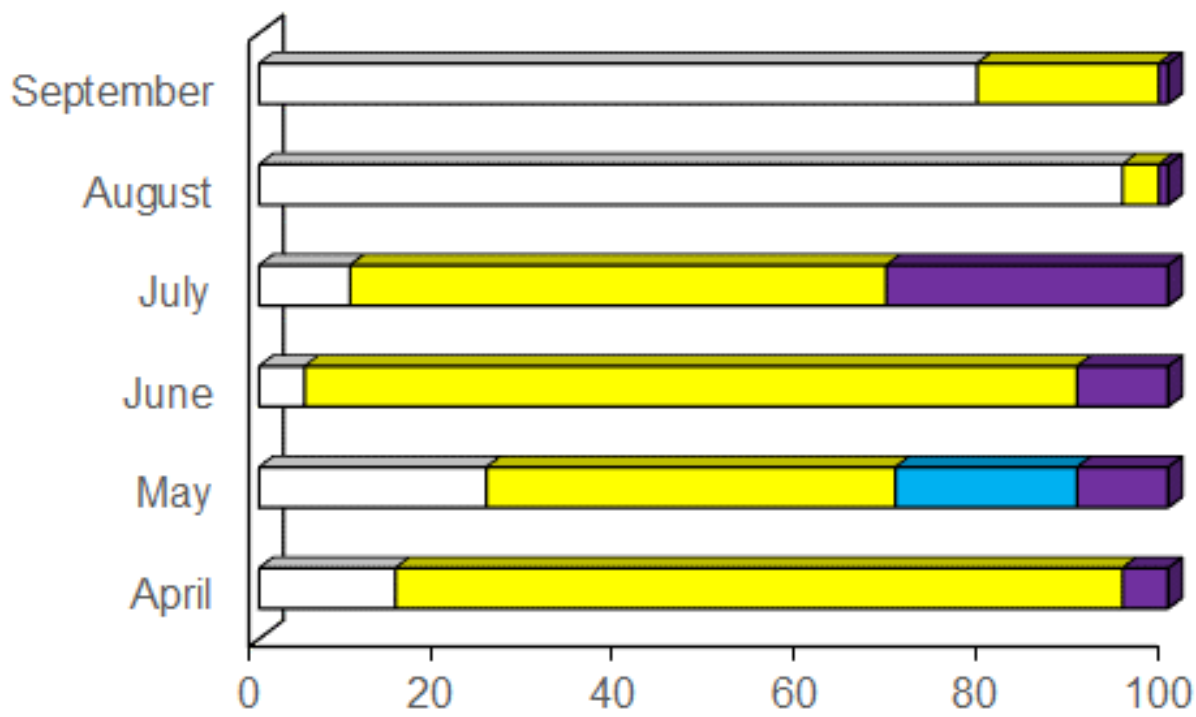

Fig 3: Percentage of blooming flower colors (average over three-year research) in the study area.

\section{Sample's determination}

During control, the captured insects was divided by colour and later determined into higher taxonomic groups (class, order, suborder) of Insects and the Arachnida by using the insect guides (Goulet \& Huber 1993; Buchar et al. 1995; McGaevin 2005; as well as using several internet resources: e.g., http://bugguide.net; https://www.fotonet.sk; https://www.galerie-insecte.org/galerie/) under laboratory conditions.

Only individuals from the order Hymenoptera were studied in more detail, which was determined into families. Two families (Apidae and Formicidae) were also determined into genus morpho groups (Tab. 3, 4).

\section{Statistical analysis}

Normal data distribution was tested using the D'Agostino-Pearson omnibus $T$ test and the Shapiro-Wilk normality test. Differences between years and colours were tested using the Kruskal-Wallis $H$ test, the MannWhitney $U$ test, and the chi-square $\left(\chi^{2}\right)$ test. All analyses were done using the GraphPad Prism version 5.01 statistical software (GraphPad Software, Inc., San Diego, California, USA). 


\section{Results}

A total of 12357 individuals belonging to the 17 higher taxa of Insecta and Arachnida were recorded during trapping in $2010-2012$ (Tab. 1).

Tab 1: List of higher taxa (class, order, suborder) of the Arthropoda and the Arachnida obtained by colour water traps in Slovakia.

\begin{tabular}{|l|c|c|c|c|c|c|c|c|}
\hline \multirow{2}{*}{ Year } & \multicolumn{2}{|c|}{$\mathbf{2 0 1 0}$} & \multicolumn{2}{c|}{2011} & \multicolumn{2}{c|}{2012} & \multicolumn{2}{c|}{$\Sigma$} \\
\hline & $\mathbf{N}$ & $\mathbf{\%}$ & $\mathbf{N}$ & $\%$ & $\mathbf{N}$ & $\%$ & $\mathbf{N}$ & $\%$ \\
\hline Order Diptera & 4042 & 53.0 & 455 & 30.3 & 1329 & 41.2 & 5826 & 47.1 \\
\hline Order Hymenoptera & 2146 & 28.1 & 482 & 32.1 & 961 & 29.8 & 3589 & 29.0 \\
\hline Order Coleoptera & 918 & 12.0 & 193 & 12.8 & 609 & 18.9 & 1720 & 13.9 \\
\hline Order Lepidoptera & 232 & 3.0 & 175 & 11.6 & 138 & 4.3 & 545 & 4.4 \\
\hline Suborder Auchenorrhyncha & 16 & 0.2 & - & - & 17 & 0.5 & 33 & 0.3 \\
\hline Order Blattodea & 26 & 0.3 & 5 & 0.3 & 17 & 0.5 & 48 & 0.4 \\
\hline Suborder Heteroptera & 11 & 0.1 & 3 & 0.2 & 1 & 0.03 & 15 & 0.1 \\
\hline Order Mecoptera & 14 & 0.2 & 43 & 2.9 & 41 & 1.3 & 98 & 0.8 \\
\hline Suborder Caelifera & 5 & 0.1 & 14 & 0.9 & 3 & 0.09 & 22 & 0.2 \\
\hline Suborder Ensifera & 28 & 0.4 & - & - & 10 & 0.3 & 38 & 0.3 \\
\hline Order Dermaptera & - & - & 3 & 0.2 & - & - & 3 & 0.02 \\
\hline Order Neuroptera & - & - & 1 & 0.07 & 1 & 0.03 & 2 & 0.01 \\
\hline Order Odonata & 2 & 0.03 & - & - & - & - & 2 & 0.01 \\
\hline Suborder Anoplura & 1 & 0.01 & 3 & 0.2 & 4 & 0.1 & 8 & 0.06 \\
\hline Order Ephemeroptera & 1 & 0.01 & - & - & 7 & 0.2 & 8 & 0.06 \\
\hline Order Siphonaptera & - & - & 2 & 0.1 & - & - & 2 & 0.01 \\
\hline Class Arachnida & 186 & 2.4 & 124 & 8.3 & 88 & 2.7 & 398 & 3.2 \\
\hline & 7628 & & 1503 & & 3226 & & 12357 & \\
\hline
\end{tabular}

Note: *published data by KOČíKOVÁ et al. (2012, 2014)

During study period, the most preferred colour was yellow, where a total of 5101 individuals were caught. The next dominant was a white (with 3655 individuals), followed by blue (1 601 ind.), purple (1 440 ind.) and the least numerous colours was red (560 ind., Tab. 2).

Moreover, comparison of trapping between years 2010 - 2012 showed a significant difference in colour preference $\left(\chi^{2}=53.97\right.$, df $\left.=8, p<0.001\right)$ for Hymenoptera. These differences in captures were also confirmed between years and colours (Figs 4, 5).

Order Hymenoptera, was second dominant order (after order Diptera) also in the period $2001-2003$ (Fig. 5). Statistical analysis showed only insignificant differences between colours depending on the year or month. The most preferred was yellow colour (1 503 individuals). The next most preferred colour was white with 1455 individuals, 1064 were captured in purple and 1005 in blue. The least visited was again the red colour (254 individuals).

A comparison of the two periods $(2001-2003$ and $2010-2012)$ revealed a significant difference between the colours $\left(\chi^{2}=146.9, \mathrm{df}=4, \mathrm{p}<0.0001\right)$. While in $2001-2003$ the order of preference was yellow, white, purple, blue, and finally red. In $2010-2012$, the third most preferred colour was blue and then purple (Fig. 5). 
Tab 2: List of higher taxa (class, order, suborder) of the Arthropoda and the Arachnida divided by colour water traps in Slovakia.

\begin{tabular}{|l|c|c|c|c|c|c|}
\hline \multicolumn{1}{|c|}{ Colour } & White & Yellow & Purple & Blue & Red & $\boldsymbol{\Sigma}$ \\
\hline Order Diptera & 1904 & 2235 & 691 & 759 & 237 & 5826 \\
\hline Order Hymenoptera & 1050 & 1376 & 475 & 541 & 147 & 3589 \\
\hline Order Coleoptera & 413 & 1057 & 81 & 117 & 52 & 1720 \\
\hline Order Lepidoptera & 144 & 212 & 99 & 62 & 28 & 545 \\
\hline Suborder Auchenorrhyncha & 11 & 9 & 1 & 8 & 4 & 33 \\
\hline Order Blattodea & 7 & 17 & 8 & 8 & 8 & 48 \\
\hline Suborder Heteroptera & 4 & 5 & 2 & 3 & 1 & 15 \\
\hline Order Mecoptera & 9 & 62 & 8 & 12 & 7 & 98 \\
\hline Suborder Caelifera & 7 & 4 & 3 & 4 & 4 & 22 \\
\hline Suborder Ensifera & 10 & 12 & 5 & 7 & 4 & 38 \\
\hline Order Dermaptera & 1 & 0 & 1 & 0 & 1 & 3 \\
\hline Order Neuroptera & 2 & 0 & 0 & 0 & 0 & 2 \\
\hline Order Odonata & 0 & 0 & 0 & 2 & 0 & 2 \\
\hline Suborder Anoplura & 3 & 2 & 0 & 2 & 1 & 8 \\
\hline Order Ephemeroptera & 8 & 0 & 0 & 0 & 0 & 8 \\
\hline Order Siphonaptera & 0 & 0 & 0 & 0 & 2 & 2 \\
\hline Class Arachnida & 82 & 110 & 66 & 76 & 64 & 398 \\
\hline \multicolumn{1}{|c|}{$\boldsymbol{3}$} & 655 & 5101 & 1440 & 1601 & 560 & 12357 \\
\hline
\end{tabular}

Note: "published data by KoČíKOVÁ et al. (2012, 2014)

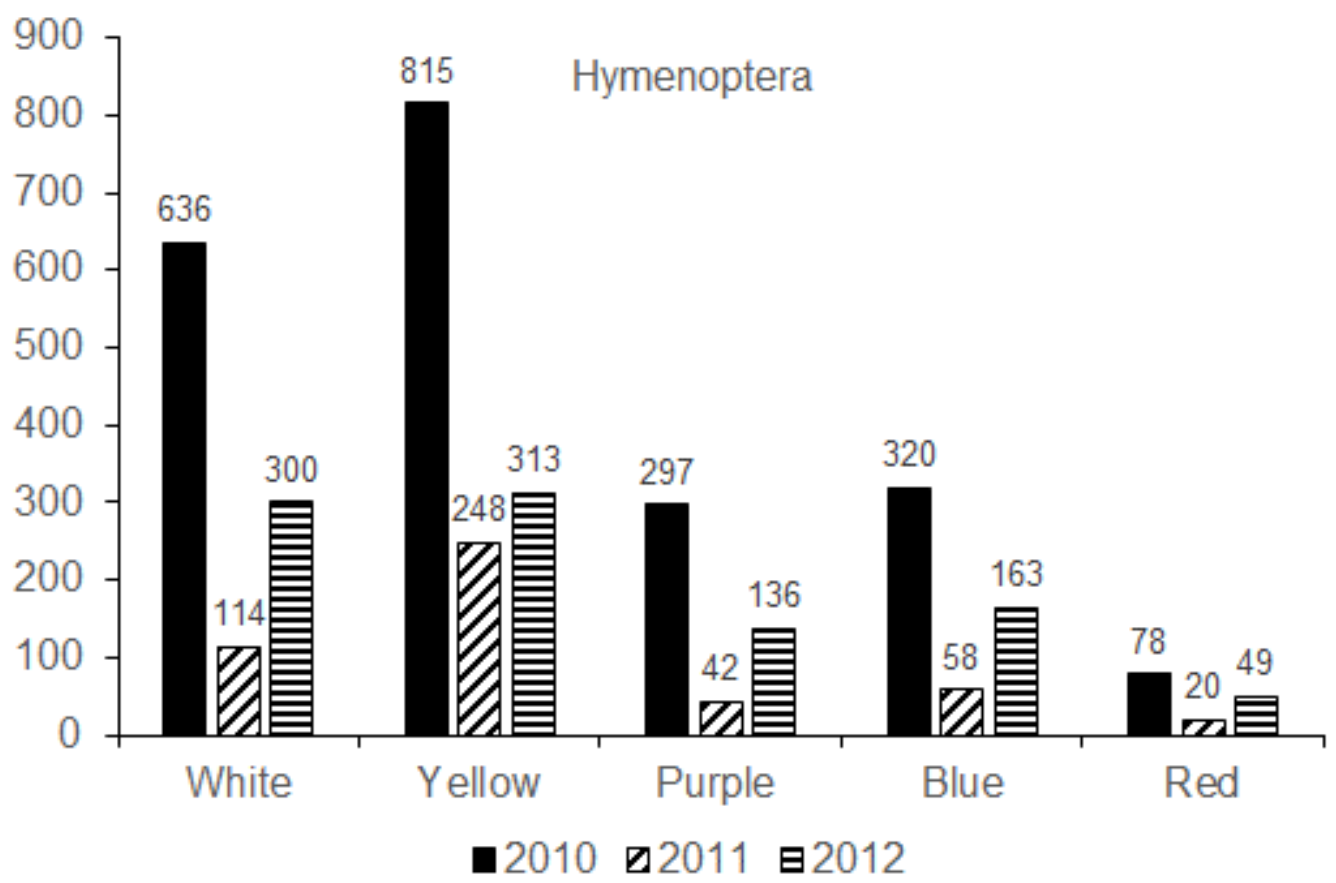

Fig 4: Comparison of the order Hymenoptera abundance in the years $(2010-2012)$. 


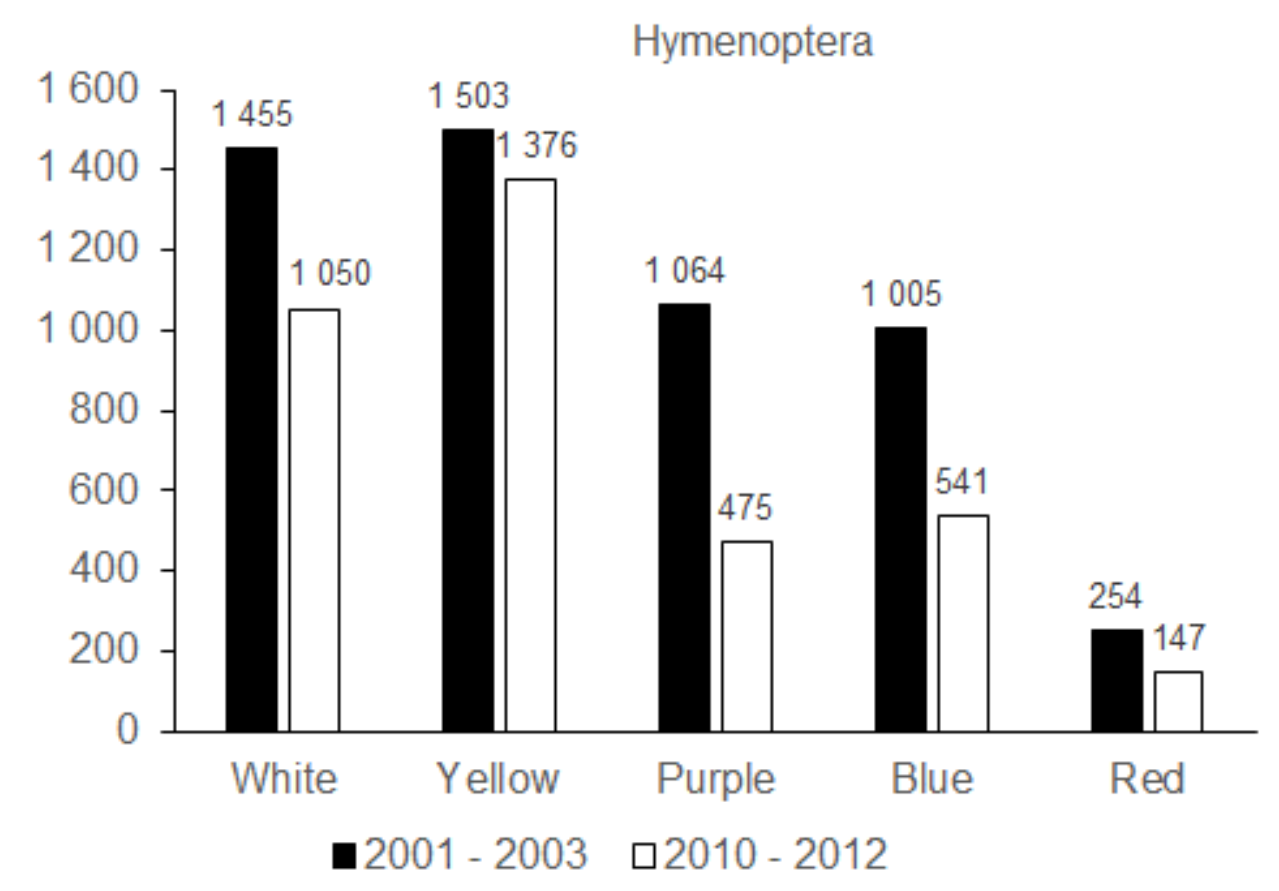

Fig 5: Comparison of the order Hymenoptera abundance in the years $(2001-2003)$ and $(2010-2012)$.

A more detailed analysis of the order Hymenoptera (only for the period 2010-2012) where collected material was determined into 18 families (Tab. 3), from which two i.e., Apidae and Formicidae were further divided into genus morpho type (Tab. 4) showed highly significant differences in colour preference for each year, respectively.

In 2010, there were higher significant differences among colours $(\mathrm{H}=21.28, \mathrm{df}=4$, $p<0.001)$, especially between white and red $(p<0.01)$ as well between yellow and red colour traps $(\mathrm{p}<0.001)$. Yellow colour traps were preferred by 12 families, then was followed by a white (5 families, namely Apidae, Vespidae, Bethylidae, Perilampidae and Cephidae). Only the Andrenidae family preferred the blue colour. Purple and red traps were not preferred by any of the observed families.

A statistically significant difference in colour preference was confirmed by the family Apidae $(\mathrm{H}=20.49, \mathrm{df}=4, \mathrm{p}<0.001)$, where Dunn's Multiple Comparison test confirmed a highly significant difference between the white and the red $(\mathrm{p}<0.001)$, the yellow and the red $(\mathrm{p}<0.01)$ and weak significance between the purple and the red $(\mathrm{p}<0.05)$. From the overall overview, white predominated in Apidae (245 individuals) over yellow (195 ind.), blue (140 ind.), purple (116 ind.) and red (8 ind.) colour traps. The most numerous genus was Apis (399 ind.), followed by Andrena (74 ind.) and Eucera (46 ind., Tab. 4). The second family, which was determined in detail into the genus morpho type, was the family Formicidae. The most represented was the genus Formica, followed by the genus Camponotus and finally genus Lasius. The most preferred colour was yellow, but a statistically significant difference was not confirmed $(\mathrm{H}=4.20, \mathrm{df}=4, \mathrm{p}>0.05)$. All data are listed in Tab. 4.

In 2011, there were slightly significant differences among traps $(H=12.85$, $\mathrm{df}=4, \mathrm{p}<0.05)$ with differences only between yellow and red $(p<0.05)$. Out of the total number of 482 individuals of order Hymenoptera, the preference for the yellow colour dominated (248 individuals). Subsequently, the colours were preferred in this order: white (114 ind.), followed by blue (58 ind.), purple (42 ind.), and the least preferred was red (20 ind.). The number of individuals in each family during this period showed that the most preferred was yellow. 


$$
\text { E }
$$




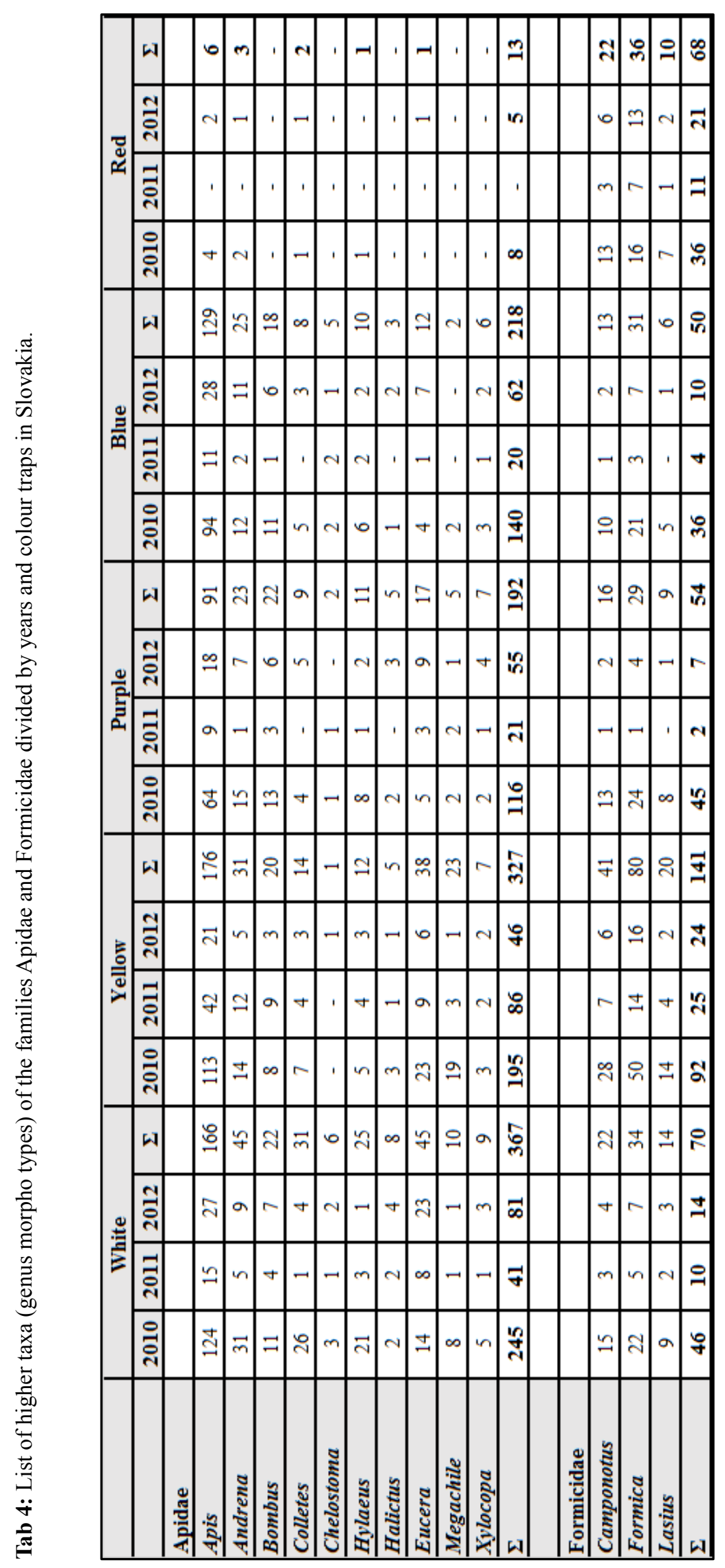


This colour was preferred by 12 of the 16 families present. Individuals from Perilampidae and Cephalidae were absent. Another dominant colour was white, preferred by three families (Diprionidae, Trigonolidae and Sierolomorphidae). The Ampulicidae family had the same occurrence in white and blue traps, while Scoliidae equally preferred white and blue traps. The red colour was preferred only by representatives of Ichneumonidae. Purple traps were not preferred by any of the families observed.

In the preference of the family Apidae, a slight high statistically significant difference was confirmed $(\mathrm{H}=23.65, \mathrm{df}=4, \mathrm{p}<0.001)$. Dunn's Multiple Comparison test confirmed a high statistically significant difference between the yellow and the red $(p<0.001)$ and the white and the red $(\mathrm{p}<0.01)$. In this year, family Apidae was dominated by yellow (86 ind.) over white (41 ind.), purple (21 ind.) and blue (20 ind.). The red water traps were without individuals. The most numerous genus was Apis (77 ind.), followed by Eucera (21 ind.) and Andrena (20 ind., Tab. 4). For genera of the Formicidae family, the test did not confirm a statistically significant preference for the individual colours $(\mathrm{H}=9.07$, $\mathrm{df}=4, \mathrm{p}>0.05)$. The most represented was the genus Formica, followed by the genus Camponotus and finally Lasius. The most preferred color was yellow (Tab. 4).

In 2012, there were significant differences $(H=15.77, \mathrm{df}=4, \mathrm{p}<0.01)$ between white and red $(p<0.015)$ and between yellow and red colour traps $(p<0.01)$. Of the total number of 961 individuals of hymenopteran in 2012 (Tab. 3), the yellow colour had the most preference (313 ind.). Subsequently, the colours were preferred in this order: white (300 ind.), then blue (163 ind.), purple (136 ind.), and the least preferred colour was red (49 ind.).

A statistically significant difference $(\mathrm{H}=17.24, \mathrm{df}=4, \mathrm{p}<0.01)$ was confirmed in the preference of colours by the genera of the family Apidae. Mainly between the white and the red colour traps $(\mathrm{p}<0.01)$, the purple and the red $(\mathrm{p}<0.01)$ and the blue and the red $(\mathrm{p}<0.05)$ colour. In this year, family Apidae was dominated by white (81 ind.), blue (62 ind.), purple (55 ind.), yellow (46 ind.) and finally red (5 ind.). The most numerous genus was Apis (96 ind.), followed by Eucera (46 ind.) and Andrena (33 ind., Tab. 4). Similarly, no statistically significant preference for colours was confirmed among the genera of the family Formicidae $(\mathrm{H}=3.41$, $\mathrm{df}=4, \mathrm{p}>0.05)$. The most represented was the genus Formica (Tab. 4).

\section{Discussion}

Our results confirmed that the colour of the trap clearly influenced abundances and diversities of catches for various insect groups. Moreover, results were slightly different from results obtained in period $2001-2003$ (Gabriková 2005). She found that the most preferred was white (with 6304 individuals), followed by yellow (4 814 individuals), purple (3 553 individuals), blue (2 981 individuals), and at least the individuals caught in the red trap (1 374 individuals). Similarly, by comparing the total material captured in both investigated periods (2001 - 2003 versus 2010 - 2012), confirmed statistically non-significant difference. Similarly, non-significant difference was confirmed when was compared captured individuals in traps between both investigated periods $(2001-2003$ versus $2010-2012)$.

The decrease in the capture of hymenopteran (and other groups of insects) compared to 2001 - 2003 (Pidaná 2003; Gabriková 2005) can be explained by a change in habitat (e.g., Kenderessy et al. 2020), especially its overgrowth with shrubs, which was confirmed for butterflies (Kočíková et al. 2014). Trichromatic vision, based on ultraviolet, blue, and green photoreceptors, is typical of most insects. However, tetrachromatic vision, which includes red photoreceptors in addition to abovementioned, is no exception (Peitsch et al. 1992). In addition, for insects were exceptionally confirmed also other types of the visual system (di- to hexachromatic). Phylogenetic and molecular studies confirmed that the presence of ultraviolet, blue, and green receptors was an original feature within the entire insect family (Chittka 1997; Chittka \& Briscoe 2001). Chittka and Briscoe (2001) showed that the absence of one of these 
three receptors in some species represents a secondary loss, and red receptors occur irregularly in the insect group and have evolved several times independently of each other.

Originally, Moericke's pan traps were designed to capture flies (Diptera) using only yellow colour (Moericke 1951). This method of capture was successfully applied to other groups of insects in various modifications and using other colours (Noyes 1989; Barták 1997; Leong \& Thorp 1999; Cane et al. 2000; Beneš et al. 2000; Stephen \& Rao 2005; Toler et al. 2005; Campbell \& Hanula 2007; Roulston et al. 2007; Wilson et al. 2008; Westphal et al. 2008; Buchholz et al. 2010; Straka et al. 2010; Kočíková et al. 2012, 2014; Tao et al. 2012; Munyuli 2013; Heneberg \& Bogusch 2014).

Interestingly, for some groups of insects, a different colour preference was found. For example, Aguir \& Sharkow, (1997), recommended blue colour for the capture of family Stephanidae (Hymenoptera). For hymenopteran is known, that can recognize shorter wavelengths of visible light better than longer wavelengths. They also use the ultraviolet component of the spectrum when searching for food sources, and this differs from visible colours on individual flowers (Peitsch et al. 1992; Chittka et al. 1994). It is the one of the important reasons why to be careful when interpreting colour preference. Based on this fact, Campbell \& Hanula (2007) also explained the higher capture of hymenopteran in blue traps. The blue traps they used had the lowest wavelength of the colours used.

The bumblebees preferred flowers that reflected blue light and some bee species see white as a blue green colour (Kevan 1978; Smithon \& Macnair 1996; Leong \& Thorp 1999). Therefore, the attraction of various groups of Hymenoptera to both white and blue pan traps may be because they cannot distinguish the difference or do not discriminate between the colours (Campbell \& Hanula, 2007). Peitsch et al. (1992) found that many bee species can recognize yellow. It was also confirmed by Leong \& Thorp (1999). Our results were in accordance with this statement, because yellow and white were preferred by several groups of insects as well hymenopteran. In contrast, the blue was the third in order of preference. This could also be explained by the fact that the monitoring area was dominated by plants blooming in yellow and white. In addition, Stephen \& Rao (2005) confirmed by capture that not only olfactory stimuli (Gross \& Carpenter 1991) were important, but also the colour preference was significant.

The number of blue flowers in the monitored area was low (20\%) and was represented by one species, Veronica spicata L., which bloomed only in May. According to Slavíková (1996), in central Europe, blue flowers make up the smallest percentage of all colours, and blue flowers are typical mainly for the families Scrophulariaceae and Gentianaceae. The number of insects found in the blue traps $(7.7 \%)$ did not correspond to this small number of flowers. The blue colour was particularly attractive to Diptera, Hymenoptera and Coleoptera. However, Straka et al. (2010) in a more detailed study of the flies from Slovakia obtained by colour traps confirmed that the blue traps were not very attractive to them.

The red colour of the traps was in the last place with number of captured individuals. This was probably related to the fact that most insects have not red receptors (Chittka et al. 2001). For hymenopteran, the number of individuals which we caught in red traps during our research was only $4.8 \%(2001-2003)$ and $4.1 \%(2010-2012)$. The result was not surprising, given that in this group, the receptor for the red part of the spectrum occurs very scarce, or the recognition of the red is based on the contrast with the environment (Briscoe \& Chittka 2001).

In conclusion, the current study was one of the first studies in Slovakia to detect many insects with coloured traps, especially from the group Lepidoptera (Pidaná 2003; Kočíková et al. 2012, 2014; Csanády et al. 2018), Diptera (Gabriková 2005; Straka et al. 2010) without the presence of a pheromone (e.g., Jakuš 1998) or other attractants (e.g., Stašiov et al. 2014; Manko et al. 2019) in a short period of time and in a non-selective method. Moreover, trapping with colour traps requires low financial and time costs combined with high yields, it is good tool for 
easy sampling of local insect communities. However, other types of trapping methods (e.g., Noyes 1989; Cane et al. 2001; Roulston et al. 2007; Westphal et al. 2008; Dvoŕák et al. 2020) must be used to obtain a faunal composition in insect groups.

Nevertheless, our results confirmed that modified Moerick's color water traps can be a valuable tool in future studies of insect diversity, distribution, and seasonal numbers, as well as in better understanding of foraging behaviour. Seasonal fauna studies on insects (as well as hymenopteran) could be carried out with minimal concern for the impact of traps on the environment. Sampling by traps is also possible for a long time and more days, also repeatedly which can provide interesting data on changes in the composition of communities caused by changes in the environment. Therefore, further studies will be needed to understand colour preferences of insects.

Acknowledgements: We would especially like to thank the editor and the reviewers for providing constructive comments and for improving the manuscript. This work was supported by the Cultural and Educational Grant Agency under the contract No. 005PU-4/2019.

\section{References}

Aguir A. \& Sharkow A. (1997): Blue pan traps as a potential Metod for collecting Stephanidae (Hymenoptera). - Journal of Hymenopteran Research 6: 422-423.

Barták M. (1997): The biomonitoring of Diptera by means of yellow pan water traps. - Folia Facultatis Scientiarum Naturalium Universitatis Masarykianae Brunensis, Biologia 95: 9-16.

Beneš J., Kuras T. \& Konvička M. (2000): Assemblages of mountainous day-active Lepidoptera in the Hrubý Jeseník Mts, Czech Republic. - Biológia, Bratislava 55(2): 159-167.

Buchar J., Ducháč V., Hůrka K. \& Lellák J. (1995): Klíč k určování bezobratlých. Scientia. Praha, 313 pp.

Buchholz S., Jess A.M., Hertenstein F. \& Schirmel J. (2010): Effect of the colour of pitfall traps on their capture efficiency of carabid beetles (Coleoptera: Carabidae), spiders (Araneae) and other arthropods. European Journal of Entomology 107(2): 277-280.

Briscoe L. \& Chittka L. (2001): The evolution color vision in insect. - Annual Review of Entomology 46: 471510.

Campbell J.W. \& Hanula J.L. (2007): Efficiency of Malaise traps and colored pan traps for collecting flower visiting insects from three forested ecosystems. - Journal of Insect Conservation 11(4): 399-408.

Cane J.H., Minckley R.L. \& Kervin L.J. (2000): Sampling bees (Hymenoptera: Apiformes) for pollinator community studies: pitfalls of pan-trapping. - Journal of the Kansas Entomological Society 73: 225-231.

Chittka L. (1997): Bee colour vision is optimal for coding flower colors, but flower colors are not optimal for being coded - why? - Israel Journal of Plant Sciences 45: 115-127.

Chittka L. \& Briscoe A. (2001): Why sensory ecology needs to become more evolutionary - insect color vision as a case of point. p. 19-37. In: Barth F.G. \& Schmidt A. (eds) The ecology of sensing. Springer verlag, Berlin.

Chittka L., Schmidt A., Troje N. \& Menzel R. (1994): Ultraviolet as a component of flower reflections and the colour perception of Hymenoptera. - Vision research 34: 1489-1508.

Chittka L., Spaethe J., Schmidt A. \& Hickelsberger A. (2001): Adaptation, constraint and chance in the evolution of flower colour and pollinator colour vision. 106-126 pp. In: Chittka L. \& Thomson J. D. (eds), Cognitive ecology of pollination. Cambridge University Press, Cambridge.

Csanády A., Zapletalová L., Duranková S. \& Tamásová L. (2018): Porovnanie účinnosti dvoch relatívnych metodík pri odchyte denných motýlov (Lepidoptera) na modelovom území Košickej kotliny. Biodiversity and Environment 10(2): 38-54.

Dvořák L., Dvořáková K., Oboňa J. \& Ruchin A.B. (2020): Selected Diptera families caught with beer traps in the Republic of Mordovia (Russia). - Nature Conservation Research 5(4): 65-77.

Gabriková D. (2005): Preferencia farby kvetov hmyzom (Insecta). Diplomová práca, Ústav biologických a ekologických vied, Prírodovedecká fakulta UPJŠ, Košice, 45 pp.

Goulet H. \& Huber J.T. (1993): Hymenoptera of the world: an identification guide to families. Agriculture Canada, Centre for Land and Biological Resources Research, Ottawa, Canada, 668 pp. 
Gross H.R. \& Carpenter J.E. (1991): Role of the fall armyworm (Lepidoptera: Noctuidae) pheromone and other factors in the capture of bumble bees (Hymenoptera: Apoidea) by universal moth traps. - Environmental Entomology 20: 377-381.

Heneberg P. \& Bogusch P. (2014): To enrich or not to enrich? Are there any benefits of using multiple colors of pan traps when sampling aculeate Hymenoptera? - Journal of Insect Conservation 18(6): 1123-1136.

Jakuš R. (1998): A method for the protection of spruce stands against Ips typographus by the use of barriers of pheromone traps in north-eastern Slovakia. - Anzeiger für Schädlingskunde, Pflanzenschutz, Umweltschutz 71(8): 152-158.

Kenderessy P., Kollár J. \& Palaj A. (2020): The Impact of Historical Agricultural Landuse on Selected Site Conditions in the Traditional Landscape of the West Carpathians. - Ekológia (Bratislava) 39(4): 343-356.

Kevan P.G. (1972): Floral colors in the high arctic with reference to insect-flower relations and pollination. Canadian Journal of Botany 50: 2289-2316.

Kočíková L., Čanády A. \& Panigaj L'. (2014): Change in a butterfly community on a gradually overgrowing site. - Russian Journal of Ecology 45(5): 391-398.

Kočíková L. Miklisová D., Čanády A. \& Panigaj L. (2012): Is colour an important factor influencing the behaviour of butterflies (Lepidoptera: Hesperioidea, Papilionoidea)? - European Journal of Entomology 109: 403-410.

Leong J.M. \& Thorp R.W. (1999): Colour-coded sampling: the pan colour preferences of oligolectic and nonoligolectic bees associated with a vernal pool plant. - Ecological Entomology 24: 329-335.

Manko P., Demková L., Kohútová M. \& Oboňa J. (2019): Efficiency of traps in collecting selected Diptera families according to the used bait: comparison of baits and mixtures in a field experiment. - European Journal of Ecology 4(2): 92-99.

McGaevin G.C. (2005): Hmyz. IKAR. Bratislava, 254 pp.

Moericke V. (1951): Eine Farballe zur Kontrolle des Fluges vin Blattlausen. - Nachrichtenblatt des Deutschen Pflanzenschutzdienstes, Stuttgart 3: 23-24.

Munyuli T.M.B. (2013): Is pan-trapping the most reliable sampling method for measuring and monitoring bee biodiversity in agroforestry systems in sub-Saharan Africa? - International Journal of Tropical Insect Science 33(1): 14-37.

Niesenbaum R.A., Patselas M.G. \& Weiner S.D. (1998): Does flower color change in Aster vimineus cue pollinators? - The American Midland Naturalist 141: 59-68.

Noyes J.S. (1989): A study of five methods of sampling Hymenoptera (Insecta) in a tropical rainforest, with special reference to the Parasitica. - Journal of Natural History 23(2): 285-298.

Peitsch D., Fietz A., Hertel H., De Souza J., Ventura D.F. \& Menzel R. (1992): The spectral input system of hymenopteran insects and their receptor based colour vision. - Journal of Comparative Physiology A 170: 23-40.

Pidaná P. (2003): Preferencia farby kvetov dennými motýl'mi. Diplomová práca. Košice, Univerzita Pavla Jozefa Šafárika v Košiciach, 36 pp.

Roulston T.A.H., Smith S.A. \& Brewster A.L. (2007): A comparison of pan trap and intensive net sampling techniques for documenting a bee (Hymenoptera: Apiformes) fauna. - Journal of the Kansas Entomological Society 80(2): 179-181.

Schauer T. (2007): Svět rostlin: 1150 květin, trav, travin, stromů a kerů střední Evropy. Rebo. Praha, 494 pp.

Smithson A. \& Macnair M.R. (1996): Frequency-dependent selection by pollinators: mechanisms and consequences with regard to behaviour of bumblebees Bombus terrestris (L.) (Hymenoptera: Apidae). Journal of Evolutionary Biology 9(5): 571-588.

Sláviková Z. (1996): Farby květů a způsoby opyplování. - Živa 3: 106-108.

Stašiov S., Oboňa J. \& Svitok M. (2014): Pavúkovce (Arachnida: Opiliones, Pseudoscorpiones, Acari, Arenea) dendroteliem vybraných drevín. - Folia faunistica Slovaca 19(1): 15-21.

Stephen W.P. \& Rao S. (2005): Unscented color traps for non-Apis bees (Hymenoptera: Apiformes). - Journal of the Kansas Entomological Society 78(4): 373-380.

Straka V., Panigaj L. \& Gabriková D. (2010): True flies (Diptera) of meadows: there is a relationship to the color of flowers? - Naturae Tutela 14: 183-194.

Tao L., Mao-Ling S., Shu-Ping S., Guo-Fa C. \& Zhi-Hong G. (2012): Effect of the trap color on the capture of ichneumonids wasps (Hymenoptera). - Revista Colombiana de Entomología 38(2): 347-350.

Tischler W. (1949): Grundzüge der terrestrischen Tierökologie. Braunschwieg, Friedr. Vieweg, 219 pp.

Toler T.R., Evans E. W. \& Tepedino V. J. (2005): Pan-trapping for bees (Hymenoptera: Apiformes) in Utah's West Desert: the importance of color diversity. - Pan Pacific Entomologist 81(3-4): 103-113.

Trumble J.T. (2004): Motivating state workers with entomology. - American Entomologist 50: 10-11. 
Westphal C., Bommarco R., Carré G., Lamborn E., Morison N., Petanidou T., Potts SG., Roberts S.P.M., Szentgyörgyi H., Tscheulin T., Vaissière B.E., Woyciechowski M., Biesmeijer J.C. Kunin W.E. Settele J. \& Steffan-Dewenter I. (2008): Measuring bee diversity in different European habitats and biogeographical regions. - Ecological Monographs 78: 653-671.

Wilson J.S., Griswold T. \& Messinger O.J. (2008): Sampling Bee Communities (Hymenoptera: Apiformes) in a Desert Landscape: Are Pan Traps Sufficient? - Journal of the Kansas Entomological Society 81: 288-300.

Záleta B. (2013): Preferencia farby kvetov zástupcami jednotlivých radov z triedy Insecta. Diplomová práca, Ústav biologických a ekologických vied, Prírodovedecká fakulta UPJŠ, Košice, 66 pp.

Authors' addresses: Alexander Csanády \& Dana Dojčaková, University of Prešov, Faculty of Humanities and Natural Sciences, Department of Biology, 17. novembra 1, SK-081 16 Prešov, Slovakia.

E-mails: alexander.csanady@unipo.sk,dana.gabrikova@yahoo.com

Jozef Oboňa, University of Prešov, Faculty of Humanities and Natural Sciences, Department of Ecology, 17. novembra 1, SK-081 16 Prešov, Slovakia. E-mail: jozef.obona@unipo.sk

Lenka Zapletalová, Podlesí I/5318, CZ-760 05 Zlín, Czech Republic. E-mail: 1.zapletalova2@gmail.com

L'ubomír Panigaj, P.J. Šafarik University, Institute of Biology and Ecology, Faculty of Science, SK-041 54, Košice, Slovakia.

E-mail: lubo.panigaj@gmail.com

Boris Zálet, Športová ulica 11, SK-056 01, Gelnica, Slovakia.

E-mail: boriszaleta@gmail.com

* Author for correspondence: Alexander Csanády, alexander.csanady@unipo.sk 